盬床＼cjkstart髄膜炎および多発神経根炎症状を呈した

$$
\text { サルコイドージスの } 1 \text { 例 }
$$

東京医科歯科大学医学部神経内科

村瀬 弘 ${ }^{\circ}$

東京医科歯科大学医学部第三内科

小寺実 内村功島本達夫

綿引 定清 前沢 秀憲

\title{
A CASE OF SARCOIDOSIS WITH A MANIFESTATION OF MENINGITIS
} AND POLYRADICULONEURITIS

Hiroshi Murase, MD

Department of Neurology, Faculty of Medicine, Tokyo Medical and Dental University

Minoru Kodera, MD, Isao Uchimura, MD, Tatsuo Shimamoto, MD, Sadakiyo WATABIKI, MD and Hidenori MAEZAWA, MD

The Third Department of Medicine, Faculty of Medicine, Tokyo Medical and Dental University

\begin{abstract}
概要 䯠膜炎拉よび多発神経根炎症状を呈したサルコイドージス（サ症）の1例を報告するととも に，本邦神経サ症例を文献て険討し，本例が極めて希な症例であることを示した，症例は36才，女 性. 約 5 カ月間微熱が持続していたが, 昭和53年 4 月16日から頭痛, 悪心, 傾服傾向, 20日から全身 の不定の疼痛，下肢にはじまる上行性の運動麻瘦が出現，27日には起立不能となり，5月11日に当科 に入院した. 入院時, 発熱 $\left(37.2^{\circ} \mathrm{C}\right)$ の他は理学的所見, 一般㭘査に特別な異常なく, 神経学的に

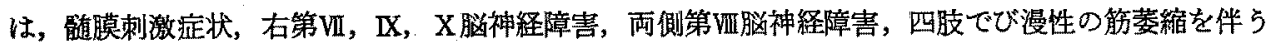

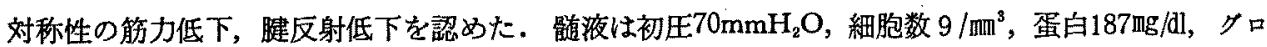
ブリン反応陽性, 糖39mg/dl, 筋電図では神経原性変化, 腓骨神経伝導速度低下の所見を得た。雨唄肺 門リンバ節腫脹, 耳下腺㕲よび斜角筋りンパ節生倹でサ肉芽腫を証明, 細胞免疫低下等の所見から, 神経サ症と訅断した。 prednisolone経口投与化より，著明改善し10月25日杖步行で退院. 文献的には， 1978年までに本邦で86例の神経サ症の報告があり，うち中权神経障害は25例 (29.1\%), 脳神経障害

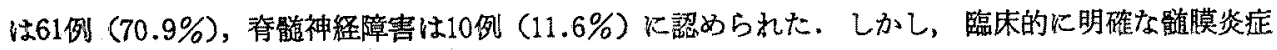
状また恃多発神経根炎症状を呈した症例の報告は極めて少なく，本症例の臨床像は希なるのと考劣報 告した。
\end{abstract}

サルコイドージス（サ症）は不明の病因による 全身性の肉芽腫性疾患であるが，神経症状を呈す る症例（神経芷症）は比較的少なく，本邦では全 サ症の $6.6 \%{ }^{1)}$, 外国でる $1.2 \sim 16 \%$, 平均 $5.1 \%{ }^{2)}$

[昭和 54 年 6 月 5 日受稿]
とされている。神経症状としては末梢性脳神経障 害が圧倒的に多く，神経せ症の約 $2 / 3$ 症例に浔

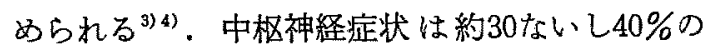
症例に認められるが35)，本邦では間脳下垂体系 の障害例が多く，脳髄膜症状，とくに髄膜炎症 例は希とされている ${ }^{3) 6)}$ ．末た末梢性脊䯣神経障 
害の発現頻度は少なく ${ }^{37)}$, 本邦では $5 \%$ ，外国 では $15 \%$ 7) と報告されて和り，一般に知覚優位の 障害が多く, 対称性の運動麻痺を来す例は少な (ㄱ) 8 .

今回われわれは，䯣膜炎症状に多発神経根炎を 合併し, 四肢躯幹に対称性の運動麻痺を来し, 起 座不能となつたサ症の 1 例を経験したので報告す る.また本邦文献により検討しえた1978年までの 神経サ症86報告例について考察を加える.

\section{症 例}

患者：36才, 主婦.

主訴：発熱, 頭痛, 四肢躯幹の異常知覚怙よ び筋力低下, 左顔面神経麻源.

家族歴：父胃癌.

既往歴：胃潰瘍 (32才), 副鼻腔炎 (35才).

現病歴：昭和52年11月頃から微熱が持続し近 医を受診していた。3 月下旬, 視力が一過性に低 下したが，約 2 週間で自然に回復した４月16日 から頭痛，悪心を訴兄食欲が低下しそれとともに 傾眠傾向が出現した.19日には四肢末梢のしびれ 感，20日よりは下肢に始まる上行性の筋力低下， 全身の不定の疼痛が加わり，27日には起立不能と なり近医に入院した。この間に嗄声, 軽度の曣下 障害も出現. 5 月 1 日の髄液検查では初圧 $150 \mathrm{~mm}$ $\mathrm{H}_{2} \mathrm{O}$, 細胞数 $21 / \mathrm{mm}^{3}$, 蛋白 $150 \mathrm{mg} / \mathrm{dl}$, Nonne Apelt 反応(十), Pandy反応(H)で，䯣膜炎の診断で， 5 月11日東京医科歯科大学第三内科に転院した.

入院時現症：身長 $160 \mathrm{~cm}$, 体重 $30 \mathrm{~kg}$, 血圧 $116 /$ $80 \mathrm{~mm} \mathrm{Hg}$, 体温 $37.2^{\circ} \mathrm{C}$, 脈拍 $86 /$ 分整, 呼吸正常. 意識は清明だがやや不安状．頭痛および項部硬 直, ケルニッ七徵候, らつ血乳頭 (2 D ) を認め た. 左側で, 末梢性顔面神経麻痺, 軽度の聴力低 下, カーテン徵候を認め, 嗄声, 臙下障害も明ら かであつた，咽頭反射は保たれており，唾液分泌 異常, 味覚異常, 聴力過敏等は認められなから た. 胸腹部の理学的所見には特別な異常を認め ず, 皮疹, 表在リンパ節の腫脹も認められなから た. 顔面を除く四肢躯幹に広範な筋萎縮が認めら れ, 四肢筋力はMMTで $2^{-} \sim 3$, 握力は検査不
能で，患者は誛がえりも不能であつた．全身に不 定の疼痛があり，四肢末梢に強いしびれ感を訴え ていたが，表在知覚，深部知覚検査では特別な異 常を認めなかつた．上肢腱反射，腹壁反射は正 常, 下肢腱反射は両側で低下ないしほぼ消失して いた．病的反射は認められなかつた．膀胱直腸障 害も認められなかつた。

検查所見：胸部X線像（（図 1) では，両側 肺門部陰影が軽度増強しているが，入院当時は特 に意味ずけをしなかつた。電困では伝導障害等 の異常を認めず正常範囲. 一般検査所見では, 血沈69mm 1 時間値, CRP (十) の他は, 末梢血, 尿, 便, 一般血清生化学で特別な異常を認めず, 血清および 尿中Ca も正常範囲であつた，髄液検 查では初圧 $70 \mathrm{mmH}_{2} \mathrm{O}$, 細胞数 $9 / \mathrm{mm}^{3}$ (リンパ 球 のみ), 蛋白 $187 \mathrm{mg} / \mathrm{dl}$, Nonne Apelt反応 $(+)$, Pandy反応 (サ), 糖30mg/dlであつた. CTscanで は脳室系の僅かな拡大, 脳波検査では広範性の徐 波化と前頭やや優位の $\theta$ 波群発を認めた．筋電図 検査では充分な患者の協力を得られなかつたが， 中間広筋, 腓腹筋, 前怪骨筋でpolyphasic action potentialを認め神経原性変化と判定した。神経伝 導速度は左尺骨神経で $52 \mathrm{~m} / \mathrm{sec}$ と正常, 腓骨神経

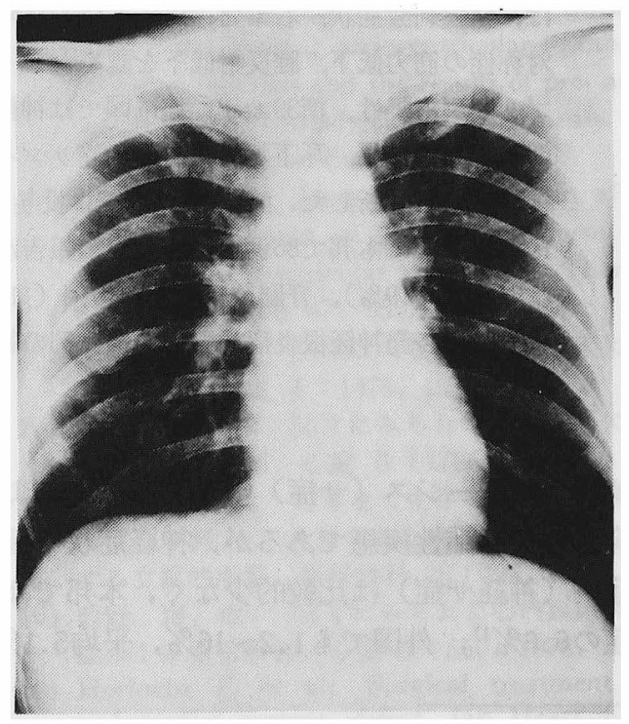

図 1. 胸部 X線像（入院時） 


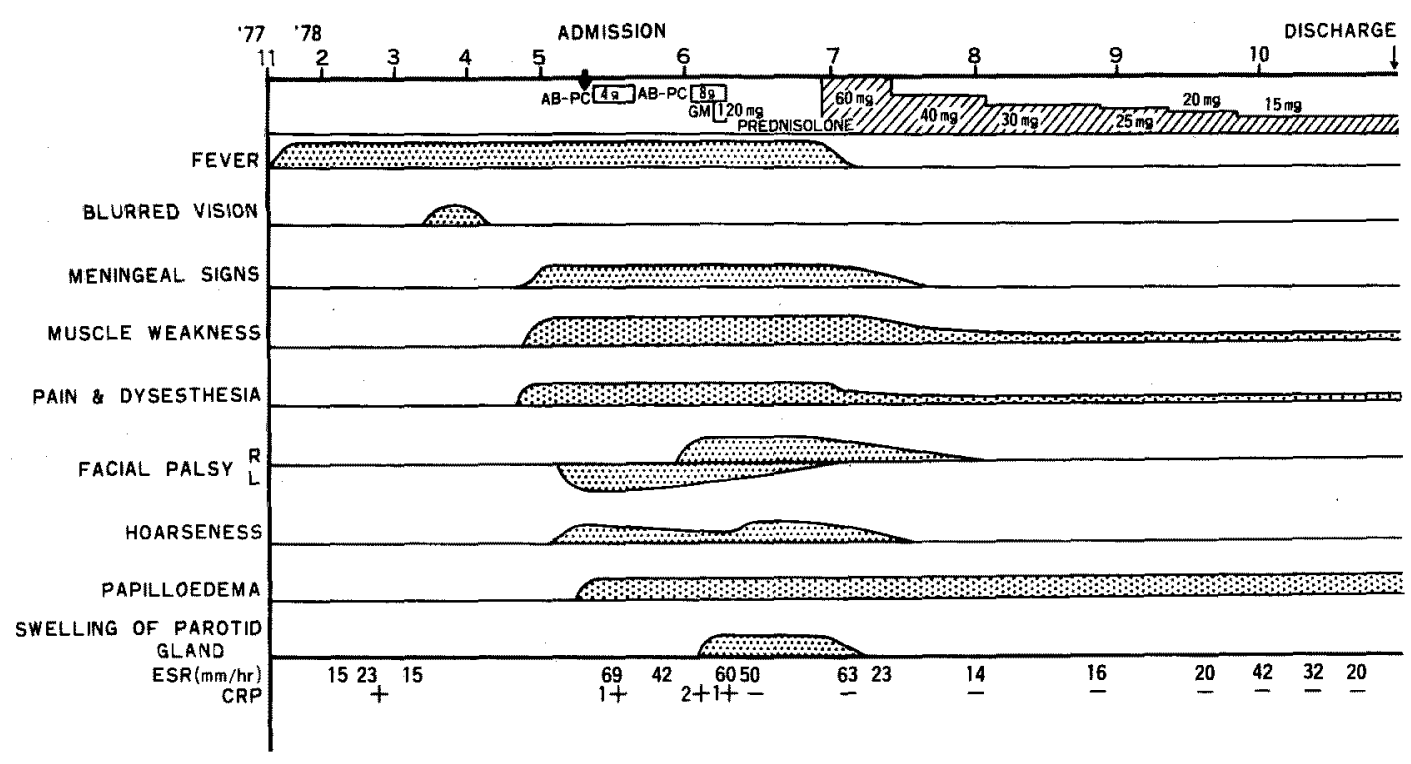

図2，䠦床経過

表 1 . 簿液検查結果扩よび経過

\begin{tabular}{l|c|c|c|c|c|c|c}
\hline \multicolumn{1}{c|}{ 施行日 (月-日) } & $5-1^{* 1}$ & $5-13$ & $6-8$ & $6-21$ & $7-12^{* 2}$ & $7-27^{* 2}$ & $8-24^{* 2}$ \\
\hline 初 王 $\left(\mathrm{mmH}_{2} \mathrm{O}\right)$ & 150 & 70 & 90 & 130 & 80 & 140 & 80 \\
細胞数 $\left(/ \mathrm{mm}^{3}\right)$ & 21 & 9 & 9 & 8 & 8 & 6 & 5 \\
総蛋白 $(\mathrm{mg} / \mathrm{dl})$ & 150 & 187 & 138 & 89 & 101 & 64 & 64 \\
Nonne Apelt 反応 & + & + & + & - & + & - & - \\
Pandy 反応 & $\#$ & $\#$ & + & + & + & + & + \\
榶 (血糖) (mg/dl) & $30(?)$ & $39(?)$ & $38(77)$ & $36(90)$ & $64(90)$ & $48(64)$ & $54(68)$ \\
\hline
\end{tabular}

発症初期に蛋白，緒胞数の增多が著明であり， prednisolone 投与後糖值が正常化している。

*1: 当科入院前データ一.

*2: prednisolone 投与徭，投与開始は6月29日.

では左 $35.7 \mathrm{~m} / \mathrm{sec}$ ，右 $41.6 \mathrm{~m} / \mathrm{sec}$ と低下していた。

経過：入院後は傾眠傾向は認められず，かえ つて興奮しやすく，不眠の訴光，強度の食欲不

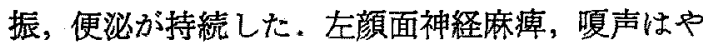
や改善の傾向にあつたが，その他の症状は不変で あつた（図 2)，好酸菌，真菌を含む感染症の検 索はいずれも陰性で発熱，䯣膜刺激症状に対して 抗生物質(ABPC $4 \mathrm{~g} /$ 日 $\times 12$ 日，8g/日×8日， GM $120 \mathrm{mg} /$ 日 $\times 4$ 日）を投与したが，無効であつた。 尿量, 尿此重は正常であつた。

髄液所見（表 1) は6月 8 日，21日と再検し， 圧，細胞数，蛋白等多少改善の方向にあつたが，
糖の低値は持続した。脳波子再三検查したが，広 沉性徐波異常で不変. 眼科的にも5つ血乳頭以外 ブドウ膜炎等特別な 異常はなく, 視力右 0.7 , 左 1.2 と保たれており，入院前の視力障害の原因は 不明であつた。聴力検査では軽度の両側性感音性 難聴, 䐅頭鏡検査では右反回神経麻瘏の所見があ つた。

5 月末より右側にも末梢性顔面神経麻痺, 数日 遅れて同側耳下腺の腫張が加わつたためサ症を疑 い, 斜角筋リンパ節, 耳下腺, 大腿四頭筋, 腓骨 神経の生㮆，ガリウムシンチグラムによるBHL の検索, 各種免疫学的検索, 血清りゾチーム值测 


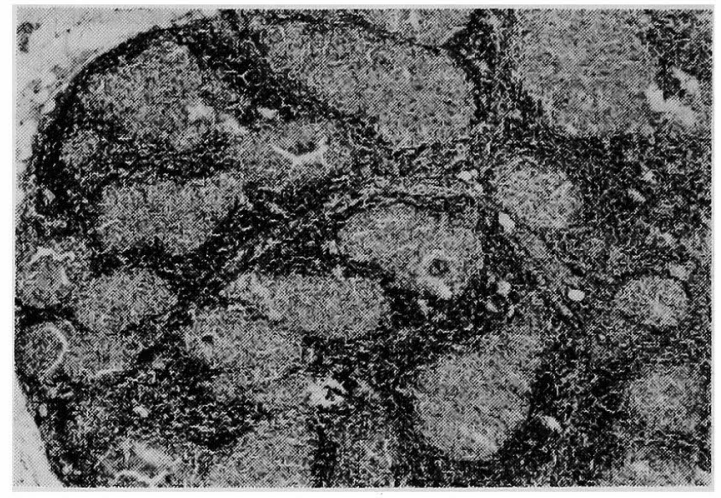

a

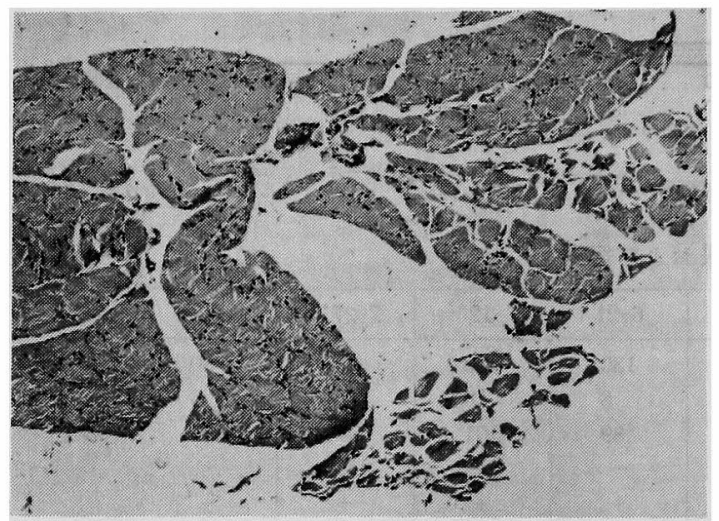

C

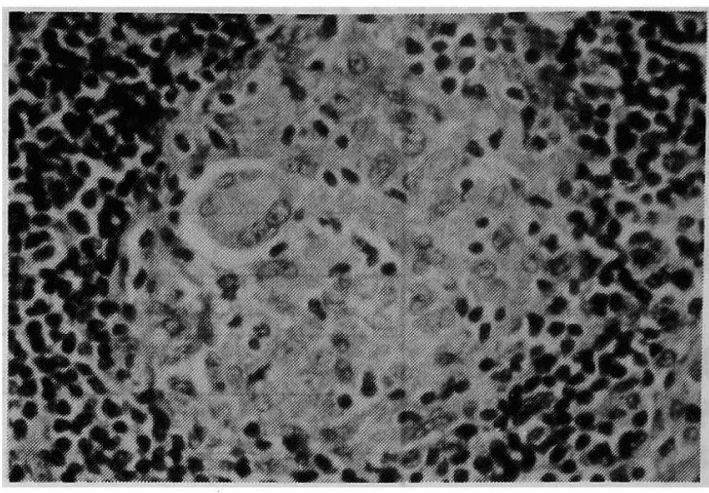

b

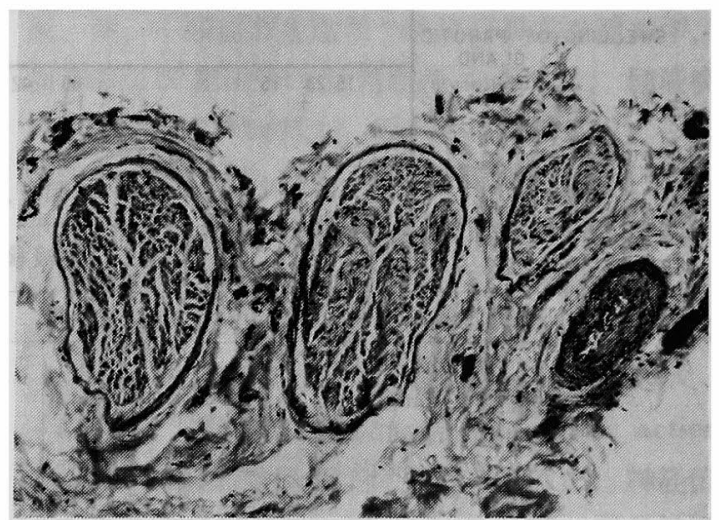

d

a： 斜角筋リンパ節 $(H-E$ 染色， ×60）：類上皮細胞結節が多発し，融合する傾向をみる．

b: 同上 (H-E染色, × 300)：結節内に多核巨細胞がみられる。乾酪壞死は認めない.耳下腺生検像も全 く同様な所見であつた。

c: 大腿四頭筋 $(\mathrm{H}-\mathrm{E}$ 染色， $\times 110) ：$ 群集萎縮を認める。細胞浸潤は認めない。

d: 腓骨神経 $(H-E$ 染色， $\times 150) ：$ 今回の生検では異常を認めない。血管周囲の細胞浸潤も僅かである。

図3.生検像.

定を行なつた。その結果，斜角筋リンパ節，耳下 腺生検像（図 $3 a, b)$ では類上皮細胞結節が多発 し，かつ乾酪化巣は認められずサ症と一致する所、 見であり，大腿四頭筋生検像（図 3c）は群集萎 縮を認め神経原性変化と判定された。腓骨神経は 伝導速度は低下していたが，生検像（図 $3 \mathrm{~d}$ ）で 見る限りでは異常を認めなかつた。ガリウムシン チグラム（図 4 a）では，肺門部に一致する陽性 像が得られBHLを診断された。免疫血清学では ッ反，PPD，DNCB，カンジダ皮内反応はいずれも
陰性， $\mathrm{T}$ 細胞割合減少 $(45.6 \%<$ 正常65～75\%) で細胞免疫低下の所見があつた。なお補体価は正 常範囲内, RA, 抗核抗体, 抗DNA抗体, LEテス ト陰性, 血清リゾチーム值増加 $(25.7 \mu \mathrm{g} / \mathrm{ml}>$ 正 常5.0 10.2 $\mu \mathrm{g} / \mathrm{ml}$ ) でサ症を示唆する所見であ つた. Kveim反応は適切な抗原が得られず施行し なかつた。

以上BHL，リンパ節耳下腺生検像，細胞免疫低 下の所見よりサ症と診断し，6 月29日 prednisolone $60 \mathrm{mg} /$ 日経口により 治療を 開始した。治療開始直 


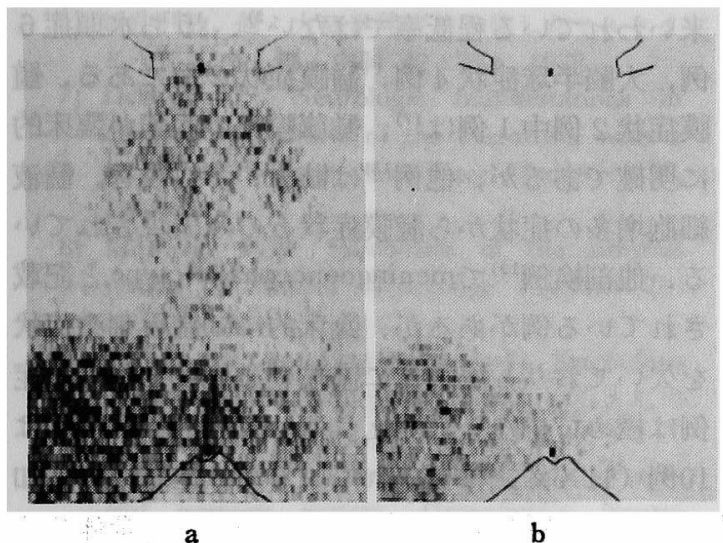

a はprednisolone 投与前, b は投与 4 週後. a で認 められた肺門部陽性像は，bでは消失している。

図 4.ガリウムシンチグラム。

後より下熱し, 頭痛, 疼痛, しびれ感等が改善し, それと共に感情的にも落ちつき, 食欲も改善し た. その他の症状る図 2 にみるよらな経過で改善 した.うつ血乳頭のみは持続した. 2 週後には寝 が方りが可能となり，4週後には起立訓練, 6 週 後には松葉杖歩行が可能となり，10月25日杖歩行 で退院した。この間の検査所見は, 䯣液 (表 1) でまず糖レベルが改善, ついで総蛋白, グロブリ ン反応, 細胞数の改善をみた。 7 月25日のガリウ ムシンチグラムでは図 4 bのようにBHL消失， 9 月14日のCT像は正常化し，9月18日の脳波所見 は正常化していた．9月13日施行の筋電図, 神経 伝導速度検査は入院時所見のまま不変であつた。

なお prednisoloneは，60mg/日 2 週，40mg/日 3 週, $30 \mathrm{mg} /$ 日 3 週, $25 \mathrm{mg} /$ 日 2 週, $20 \mathrm{mg} /$ 日 2 週と投 与し， $15 \mathrm{mg} /$ 日を維持量とした. 現在約 6 力月を 経過しているが，経過は良好である.

\section{考案}

本例がサ症であることは， BHLおよび 斜角筋 リンパ節, 耳下腺生検所見から確かで, 各種細胞 免疫低下の所見むこれをららずけている。症の 神経病変は多様で, 神経症状のみからは神経サ症 と診断することは多くの場合困難で, 他缄器でサ 症を診断されたのちにはじめて神経サ症と診断出 来るとされているが5)，本例もその例外ではなか
つた。

サ症の中枢神経系病変は, 軟脳膜病変と漏斗打 よび第 3 脳室底, 前壁病変に大別され ${ }^{10)}$, 後者は 間脳下垂体系の障害を来す，本例は髄膜炎症状が 主徵で，尿崩症を合併せず，軟脳膜病変が主体の 症例と考えられる．軟脳膜はサ肉芽腫の好発部位 で, 剖検ではしぱしば病変を認めるが5)11), 大半は 無症候性で臨床症状を呈さない?7)。臨床的には病 変が穿通血管に沿つて脳内に漫潤するか, 中脳水 道や第 4 脳室出口で䯣液の流通を障害して発症す る例が多く3)6)11)，本例のように髄膜炎症状を呈 する例は少ない，また本例で認められた易興帛 性, 強度の食欲低下, 便泌, 脳波異常は脳内病変 を，また軽度ではあるが，CT像で認められた脳 室系拡大は䯣液流通障害の可能性を示唆する。い ずれもprednisolone投与後に改善している．䯣液 異常は中枢神経サ症で必らずしも認められるも のではないが8)，圧，細胞数，蛋白の増加は70\% 程度の症例に, 糖低下は $18 \%$ に認められるとさ $れ^{12)}$ ，糖低下は広範な䯣膜障害の結果とされてい

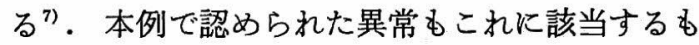
のであるが, 細胞数増加, 蛋白増多は発症早期に 著明であり，糖レベルはprednisolone投与後改善 てており，軟脳膜病変の推移を反映しているょう で與味深い。な拉，䯣液蛋白増多はこれと平行し ないが，本症例では多発神経根炎と似た脊髄神経 障害を合併して扣りその点考慮の必要があろう。

本例で認められた脊䯣神経障害は, 根症状を伴 表 2. 本邦神経症86例の集計

\begin{tabular}{|c|c|c|c|}
\hline \multicolumn{3}{|c|}{ 1. 中权神経障害を示す例 } & \multirow{5}{*}{25 例*1 $(29.1 \%)$} \\
\hline 水頭症 & 6 例 & \multirow[b]{2}{*}{ 12例 } & \\
\hline 大遒半球障害 & 4 例 & & \\
\hline 髄膜症状 & 2 例 & & \\
\hline 尿崩症 & & & \\
\hline \multicolumn{3}{|c|}{ 2. 末梢性冷髄神経障害を示す例 } & 10 例*2 $(11.6 \%)$ \\
\hline \multicolumn{3}{|c|}{ 3. 末梢㤔脳神経障害を示す例 } & 61 例*3 $(70.9 \%)$ \\
\hline \multicolumn{4}{|c|}{ *1：1 例は膸膜炎症状と尿崩症を合併 } \\
\hline \multicolumn{4}{|c|}{ *2：5ち2 例は中枢神経障害に合併 } \\
\hline \multirow{2}{*}{\multicolumn{4}{|c|}{ 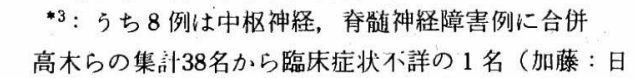 }} \\
\hline & & & \\
\hline \multicolumn{4}{|c|}{ 胸疾会誌 $5: 79,1967 ）$ を除く37例に1978年迄の文献例 } \\
\hline \multicolumn{4}{|c|}{ を加えて集計した。 } \\
\hline
\end{tabular}


5上行性運動麻痺, 䯣液細胞蛋白解離, 筋電図変 化，神経公導速度遅延，筋生検所見等，多発性神 経根炎の臨床像とよく一致する。Mahtews ${ }^{\mathrm{a})}$ はサ 症による猆䯣神経障害は, 対称性の多発性神経根 炎の型を呈さないとしているが，Strickland ${ }^{13)} ら$ は本症類似の症例を, sarcoidosis with a LandryGuillain-Barré syndrome として報告している。本 症例でむ，末梢性脊骨道神経障害の特徵を持つた上 行性麻㽻が，サ症の中权病変とほぼ一致した時期 に，他に原因とすべき異常もなく発現しており， サ症に関連する多発神経根炎である可能性が強 い，サ症に括ける春髄神経障害の機序は現在なお 不明で, 肉芽腫の浸潤による直接障害 ${ }^{13)}$, 代謝毒 素等による間接的障害 ${ }^{(4)}$, その両者である可能

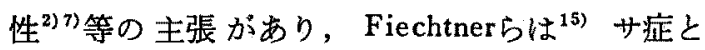
重症筋無力症の 合併例, および前記Strickland ${ }^{13)}$ の例をあげ共通する免疫異常の重要性を指摘して いる. 本例の場合は急速に発症し, 上行性麻疸の 形をとつており，肉芽尰による直接障害とは考元 難い。なんらかの全身的な機序を介して，多発神 経根炎を合併したと考学易い。

本例では第 III， VIII， IX，X脳神経の障害を合併 した。これらはサ症で最も障害されやすい脳神経

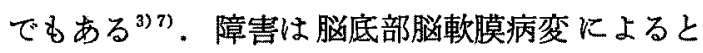
の説 ${ }^{11}$ むあるが，本例の第VII脳神経を除く，第 VII，IX，X脳神経障害は顔面神経管出口より遠 位, 哂頭枝, 反回神経の障害でむしろ耳下腺部や 咽頭壁での局所的変化による可能性がある7 ${ }^{16)}$. また第VII，IX，X脳神経は多発神経根炎に合併し やすい異常である点も考慮する必要があろう。

本邦における神経サ症の臨床報告例は，われわ れが文献で検討し 得た範围では，1972年の高木 ら"の集計以降1978年迄に49例で，高木らの集計 中臨床症状不詳の 1 例 (加藤; 日胸疾会誌, 5 : 79，1967）を除く37例と合わせて86例となる。そ れらを主症状により分類して表 2 に示した．中枢

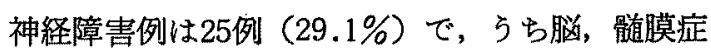
状12例, 尿崩症14例であり，1例で両者を合併し た。脳，檤膜症状を呈した例は12例 (48\%) で従
来いわれている程低率ではない3)。5ち水頭症 6 例, 大脳半球症状 4 例, 鹃道膜症状 2 例である. 髅 膜症状 2 例中 1 例は ${ }^{17)}$, 䯣脳膜炎の症状が臨床的 に明確であるが, 他例 ${ }^{18)}$ は眩量, 歩行障害, 䯣液 細胞增多の症状から䯣膜症状とのみ表現されてい る. 他剖検例 ${ }^{19)}$ でmeningoencephalitictype と記載 されている例があるが，臨床的には䯣膜刺激症状 を欠いており，臨床的に噵膜刺激症状を呈した症 例は極めて少ないといえょう、春䯣神経障害例は 10例 (11.6\%) 報告されているが，他に疼痛等知 覚異常の記載されている例が5例あり，全体では 松井 ${ }^{16)}$ のいらように決して少なくはない，しかし 大半は知覚優位の障害で, 運動障害は軽度かつ単 発性である。重篤な運動障害は 2 例のみで，とも に歩行不能. ただし 1 例 ${ }^{199}$ は下肢しびれ感脱力の ため歩行不能とのみ，他例 ${ }^{20)}$ は筋力に関する記載 はなく, 腱反射減弱, 知覚障害のみが記載されて いるにすぎないまた 2 例とも髄液蛋白量は正常 範囲であつた。したがつて本症例のように，骮膜 刺激症状を呈し，多発神経根炎類似の広範な春䯣 神経障害を合併したサ症は，極めて希な症例と考 えられる。

\section{結 論}

36才, 女性のサ症患者に䯣膜资, 多発神経根炎 症状を呈した 1 例の臨床経過を報告し，若干の考 察を加えると共に, 本邦神経サ症文献例と比較し た.

\section{文献}

1) 本間日臣, 他：昭和 47 年度サルコイドージス 全国疫学調查成績 一二次調查一。昭和 48 年度 厚生省特定疾患サルコイドージス調查研究班 業績 1974, p. 17.

2) Mayock RL, et al: Manifestations of sarcoidosis. Analysis of 145 patients, with a review of nine series selected from the literature. Amer J Med 35: 67, 1963.

3) 本田虔夫, 高木洲一郎：サルコイドーシスと 神䅅系。内科 $34: 223,1974$.

4) Colover J: Sarcoidosis with involvement of the nervous system. Brain 71: 451, 1948.

5) Silverstein $A$, et al: Neurologic sarcoidosis, study of 18 cases. Arch Neurol 12: 1, 1965. 
6) 新井利政, 他：大脳半球症状を呈したサルコイ ドージスの 1 例. 内科 $42: 354,1978$.

7) Delaney P: Neurologic manifestations in sarcoidosis, Review of the literature, with a report of 23 cases. Ann Inter Med 87: 336, 1977.

8) Mathews WB: Sarcodosis of the nervous system. J Neurol Neurosurg Psychiat 28: $23,1965$.

9)高木洲一郎，他：神経症状を伴つた Sarcoidosis の症例一本邦例と欧米例の比較を中心として 一. 踠床神経学 $12: 282,1972$.

10) Hariman DGF: Bacterial infections of central nervous system. Greenfield's Neuropathology. 3rd ed. Edward Arnold Pub. Ltd. 1976, p 238.

11) Herring $A B$ and Urich $H$ : Sarcodosis of the central nervous system. J Neurol Sci 9: 405 1969.

12) Gaines JD, et al: Low CSF glucose level in sarcoidosis involving the central nervous system. Arch Inter Med 125: 333, 1970.

13) Strickland GT and Moser KM: Sarcoidosis with a Landry-Guillain-Barré syndrome and clinical response to corticosteroids. Amer J Med 43: 131, 1967.

14) Wells CEC: The natural history of sarcoidosis. Proc R Soc Med 60: 11721967.

15) Fiechtner $J$ et al: Sarcoidosis in the nervous system. Ann Inter Med 88: 131, 1978.

16) 松井泰夫：サルコイドージ、神経内科 3 : $419,1975$.

17）正木弘美，新海法：特異な症状を呈したサル コイドーシスの3 例. 皮有 $14: 253,1972$.

18）長井勇, 他: 発熱, 意識障害, 多尿. 日本臨 林 $94: 792,1975$.

19）河辺秀雄，他：檤膜症状を伴つたサルコイドー 棌の 1 例(会)。日胸疾会誌 $9: 612,1971$.

20) 松井泰夫, 他: 神経系のサルコイドージ、最 新医学 $27: 1293,1972$.

21）石上隆一，他：多彩な症状を呈したサルコイ ドージスの 1 症例. 内科 $31: 994,1973$. 